\title{
The Role of Technology in the Efficiency and Growth of Banking Sector in Jordan
}

\author{
Sameer A. A. AlZoughool ${ }^{1 *}$, Proff Ahmed Azrin Adnan², Dia Khalaf Ahmed AlQatawneh ${ }^{3}$, Tamer Hussain Ahmad
} AlQudah $^{4}$

${ }_{1,3,4} \mathrm{Phd}$ Students, UniSZA University, Kuala Terengganu, Malaysia

${ }^{2}$ Lectrure, UniSZA University, Kuala Terengganu, Malaysia

DOI: $10.36347 /$ sjebm.2020.v07i01.004

| Received: 02.12.2019 | Accepted: 14.12.2019| Published: 29.01.2020

*Corresponding author: Sameer A. A. AlZoughool

Abstract

Review Article

Information technology and communication development processes are two interrelated and fundamental aspects of the banking sector. Banking sector is considered as the integral part of the economic development; however, if it does not progress well and collapse, the economy will also be collapsed. The recent recession in the European banks and the impacts of globalization, competitive forces of the market and the innovation in the banking industry make it important to understand how several aspects of the consumer behavior impact the innovation and thus the respond made by the bank and deliver its customer services. considering the significance of information and communication technology and the role of innovation and competition in the banking sector, the present paper provides a critical review of the previous studies and the core objective of the paper is to examine the role of information and technology on the efficiency and growth of the banking sector in terms of improved customer service delivery and banks overall performance. The present paper also offers a critical review of the peer reviewed articles and scholarly articles about the influence of IT on bank's productivity to investigate if the banks have progressively attained customer service delivery and provide high level of customer satisfaction by utilizing its online delivery services other than minimizing operational cost and profit generation.

Keywords: Technology, Efficiency and Growth, Banking Sector.

Copyright @ 2020: This is an open-access article distributed under the terms of the Creative Commons Attribution license which permits unrestricted use, distribution, and reproduction in any medium for non-commercial use (NonCommercial, or CC-BY-NC) provided the original author and source are credited.

\section{INTRODUCTION}

Information technology has brought a complete transformation in the bank's overall performance and particularly on the delivering customer services. According to Abid \& Goaied [1] to compete in this global era and enhance the quality of the customer services along with eradicating the transaction cost, online services and many other digital technologies have influenced the banking sector; consequently, they are busy in providing value added services to its customers. This is further illustrated by Colesnic, Kounetas \& Michael [2] that IT development has developed the user friendly banking services and so proved to enhance the efficiency of the banking services. Nevertheless, Jreisat Hassan \& Shankar [3] mentioned that customer satisfaction and providing customer services in efficient manner are the prime factors for banks to ensure that how progressively the technology facilitates the bank to attain the increased market share and customer base. In this context, the present paper has the objective to investigate what previous researchers have examined about the influence of the IT on the bank's efficiency and customer services [4].

In the context of Jordan banking sector, however, banking sector is the core element of the country's economic development because it established a new infrastructure and turn the country a genuinely global economy in terms of robust private sector investment. Moreover, electronic banking/digital banking has been validated as the useful mechanism in the banking sector and has exclusively revolutionized the way of executing business activities and particularly banking industry because it poses a great challenge for the business investors to choose the financial institute that can have intense business structure /model to compete in this global business landscape. Considering this significance, another objective of this paper is to investigate the previous literature on the impact of investing in the technology by Jordan banks. 


\section{Theoretical Background}

To understand the influence of IT on the bank's efficiency and providing customer service delivery, the researcher used several previous articles, journals and related literature and studied existing practice in the banking industry in the Jordan. Nowadays, as illustrated by Tzeremes [5], competition, and globalization has enforced the banking services to provide 24 hours customer delivery services around the world, whereas, the notable drawback lies in its security reasons and the unease of providing digital services due to lack of sufficient resources.

However, the association that focuses on the expenditure of IT on the banking efficiency is dependent on the scope of the network impact. If the banks are likely to adopt efficient IT services, it can exclusively eliminate the payroll expenses, strengthen market share due to increase in customer services and consequently it can increase the profit of the bank. Moreover, by viewing the impact of IT on the banking efficiency from the broader perspective, it could also eradicate the income streams of banks and so the strategic response of the banks. The trends towards the internal cutting of cost, mergers and acquisition are changed in the banking industry. The purpose of the present paper is to determine if banks in the Jordan have increased its income propensity after the use of IT in its business structure or not, consequently, the provision of high quality service delivery as compared to the traditional way of providing services. The major issue that can impede the customers from being positive towards the implication of IT in the banking sector is due to its inconvenience aspect and in certain occasions, its incompatibility with their life style can become a major issue for them to favor it.

\section{The role of Information technology in banking industry}

For every business, there is a potential for crisis if it does not meet the market criteria and ascertain consumer satisfaction. However, in the banking sector, there is always a potential for crisis, which can make the bank last an insufficient. For this purpose, advance technology that is also supported by the superior tools can ensure that IT has attained the needed processes inadequacy, consequently, advanced IT system that is underpinned by a high quality mechanism is needed in the banking sector to ensure that IT has attained the needed processes. A review of the articles [6] reveals that IT may have negatively affect bank's efficiency and decrease their productivity. However, Komal \& Abbas [7] claim that with the decrease in the technological growth in the banking sector, the decrease in the business growth is observed. Similarly, also identified that IT is one of the crucial factors and the consumer interest for those banks are increased that have robust technology and efficient services to its customers. There are various literatures that confirm the positive impacts of IT on the business value in the banking sector. Komal \& Abbas [7] conducted the survey that revealed that IT enhances the customer delivery services. Another study conducted by Stewart, Matousek \& Nguyen [8] also encouraged the use of IT for banking industry in the US. Agwu [9] investigated the impact of IT evolution on the profit and cost efficiency in the banking sector for 2013-2017 and found that there is a significant association between the IT, productivity of the bank and cost saving pattern. Likewise, Mittal [10] concluded that IT capital provides $82 \%$ increase in marginal output, whereas, non IT business model provides only $6 \%$. This concludes that IT can facilitate the banking operations and strengthen its banking procedures to attain standardized and value added transactions.

\section{Information Technology and bank's efficiency in Jordan}

Although, the extensive research studies are majorly about the impact of IT on the banking sector in the western countries such as UK, US and European countries, however, from the perspective of the Jordan banking industry, the scholars are needed to expand their research on the impact of IT on the banks' efficiency and totality. To find out the impact of IT on the Jordan's banks efficiency, previous literature reveals that there is intensive research studies that confirm the significance of electronic banking on the bank's overall efficiency in Jordan banks [11]. For instance, Jreisat, Hassan \& Shankar [3] revealed that the commercial banks in the Jordan offer digital banking services, which provide higher returns on the equity employed by the business model. IT is determined as one the leading factors that influence the bank's profitability in the period under study [1]. Zhu, Wang \& $\mathrm{Wu}$ [4] also observed that the profitable banks in the Jordan are exclusively adopting IT in their business models. on the other side, there are certain studies that reveal that those banks that have adopted IT in their business model are not the primary movers in the market. on the same note, Mansour \& El Moussawi [12] revealed that there is not significant impact of IT on the banking performance, however, further research may be needed to conclude the result for all banking sector, globally. However, Shoebridge [13] revealed that IT in the banking industry can facilitate the global economies to establish a financial system that helps them to implement its financial infrastructure in an improved manner. In the context of the Jordan banks, the present paper studied the annual reports of the various banks, those who have implied IT in their business model since years. The difference in their profit revenue revealed that the banks are promoting their services and products using electronic mechanism and the implication of IT in their business model improve their overall efficiency and so the customer satisfaction. This finding confirms the previous research conducted by Menicucci \& Paolucci [14] that the internet banking is observed as the complimentary mechanism for those banks that 
have increasing concerns for their customer satisfaction and penetrates market with their robust technology.

\section{The role of IT, customer service delivery and the banking sector in Jordan}

Kumar, Charles \& Sekhar Mishra [15] presented their view that enormous models in the banking sector in the Jordan that have main focus on the customer services emphasize on the comparative analysis of anticipated services and the actual performance, leads to the two influential judgments of perceived service quality and increased customer satisfaction. For instance, 1) those customers who attain service delivery of the banks compare their expectations before their confrontation with the banking services, 2) customers formulate their perceptions when at the time of availing service delivery and then they compare their expectations with the actual services provided from the banks. Therefore, it exhibits that customer anticipation about the banking services are unique and can significantly influence the customer assessment of service delivery and customer satisfaction.

Customer satisfaction is described by Casolaro \& Gobbi [16], which are intangible are easily imitated, however, it depends on those people who are involved in providing services and are predominated by mechanized system [17] and information technology in this global world of digitalization [1]. The banks that have included high tech services [7] are majorly customer focused. Consequently, such banks service delivery are competitive in the market and provide improved customer service delivery. In the context of Jordan banking industry, according to Agwu [9] the frequent issues faced by the customers are transaction errors, limited customer service delivery and long lines, however, the emerging technological implications in the banking sector has expanded the survival of the banking strategies and changed the perspective of customers about the banks and its relationship with their customers.

\section{Consumer attitude in the banking industry}

The increasing globalization and digitalization in the business landscape have profoundly affected the consumer behavior and attitude towards a specific company. The increase in customer awareness and living standards due to increase in trend towards urbanization and modernization, banking industry is under constant pressure to modify their products and service features and strengthen customer services. For this purpose, the consumer behavior is essential to be studied, so that the banks could collect the data and information about the customer likes and dislikes for specific feature or product services. According to Adesina \& Ayo [18], there are seven marketing elements i.e. 7Ps in the banking industry that must be focused to strengthen its strategic approach towards its customers, which are; product, price, promotion, process, people, place, and physical evidence. This is further elaborated by Komal \& Abbas [7] that customers in the banking sector want convenience and operational efficiency in terms of efficient and effective transactions so that they can attain the benefit from the bank's competitive edge

\section{CONCLUSION}

However, the banking industry is facing enormous challenges due to globalization and competition due to increasing focus on the information technology. The implication of IT can results in the reduction of cost, however, the impact on the profitability of the banks is inconclusive because it is likely to affect the workers in the bank. Moreover, it can also raise issues to the banks because it puts enormous pressure on the bank to meet customer demands and fulfill their anticipated customer service delivery. Whilst reviewing the previous literature about the implication of IT in the banking sector confirms the significance of IT mechanism in the improved customer delivery services and overall efficiency of the bank is also strengthened, however, in the context of Jordan banks, further research is required by the researchers on various banks at different time frames to understand the significance of IT on the efficiency of the banking operations.

\section{REFERENCES}

1. Abid I, Goaied M. A meta-frontier assessment of bank efficiency in Middle East and North Africa countries. International Journal of Productivity and Performance Management. 2017 Feb 13;66(2):26696.

2. Colesnic O, Kounetas K, Michael P. Estimating risk efficiency in Middle East banks before and after the crisis: A metafrontier framework. Global Finance Journal. 2019 Jul 20:100484.

3. Jreisat A, Hassan H, Shankar S. Determinants of the productivity change for the banking sector in Egypt. InGlobal Tensions in Financial Markets 2018 Mar 19 (pp. 89-116). Emerald Publishing Limited.

4. Zhu N, Wang B, Wu Y. Productivity, efficiency, and non-performing loans in the Chinese banking industry. The Social Science Journal. 2015 Dec 1;52(4):468-80.

5. Tzeremes NG. Efficiency dynamics in Indian banking: A conditional directional distance approach. European Journal of Operational Research. 2015 Feb 1;240(3):807-18.

6. Hoppermann J. Banking of the Future: How Banks Will Use Digital Capabilities to Remain Competitive. Forrester Research. 2015 May;18.

7. Komal R, Abbas F. Linking financial development, economic growth and energy consumption in Pakistan. Renewable and Sustainable Energy Reviews. 2015 Apr 1;44:211-20.

8. Stewart C, Matousek R, Nguyen TN. Efficiency in the Vietnamese banking system: A DEA double 
bootstrap approach. Research in International Business and Finance. 2016 Jan 1;36:96-111.

9. Agwu E. The role of e-banking on operational efficiency of banks in Nigeria. Available at SSRN 3122498. 2018 Feb 12.

10. Mittal A. Advertising and Sales Promotion, Wisdom Publication, New Delhi. 2008

11. Hernando I, Nieto MJ. Is the Internet delivery channel changing banks' performance? The case of Spanish banks. Journal of Banking \& Finance. 2007 Apr 1;31(4):1083-99.

12. Mansour R, El Moussawi C. Efficiency, technical progress and productivity of Arab banks: A nonparametric approach. The Quarterly Review of Economics and Finance. 2019 Apr 10.

13. Shoebridge M. Banking on six sigma to improve service quality a case study: major Australian financial institution. Australian Banking \& Finance. 2005;14(9-10).
14. Menicucci E, Paolucci G. The determinants of bank profitability: empirical evidence from European banking sector. Journal of Financial Reporting and Accounting. 2016 Jul 4;14(1):86-115.

15. Kumar M, Charles V, Mishra CS. Evaluating the performance of indian banking sector using DEA during post-reform and global financial crisis. Journal of Business Economics and Management. 2016 Jan 2;17(1):156-72.

16. Casolaro L, Gobbi G. Information technology and productivity changes in the banking industry. Economic Notes. 2007 Feb;36(1):43-76.

17. Skinner C. Digital bank: Strategies to launch or become a digital bank. Marshall Cavendish International Asia Pte Ltd; 2014 May 15.

18. Oni AA, Ayo CK. An empirical investigation of the level of users' acceptance of e-banking in Nigeria. Journal of internet banking and commerce. 2010;15(1):1-3. 